\title{
Screening for insulin receptor gene DNA polymorphisms associated with glucose intolerance in a Scandinavian population
}

\author{
M.Sten-Linder ${ }^{1}$, S. Vilhelmsdotter ${ }^{1}$, A. Wedell ${ }^{1}$, I.Stern ${ }^{1}$, T.Pollare ${ }^{4}$, P. Amer ${ }^{2}$, S. Efendić ${ }^{3}$, R. Luft ${ }^{3}$ and H. Luthman $^{1}$ \\ ${ }^{1}$ Department of Clinical Genetics, Karolinska Institute, Karolinska Hospital, ${ }^{2}$ Department of Medicine, Karolinska Institute, \\ Huddinge Hospital, ${ }^{3}$ Department of Endocrinology, Karolinska Institute, Karolinska Hospital, Stockholm, \\ ${ }^{4}$ Department of Geriatrics, University of Uppsala, Uppsala, Sweden
}

\begin{abstract}
Summary. The significance of insulin receptor gene variants in the aetiology of Type 2 (non-insulin-dependent) diabetes mellitus has been investigated by analysis of restriction fragment length polymorphisms in a genetically homogeneous Swedish population. Seven polymorphisms were analysed, spanning functionally important regions of the insulin receptor locus. Four of these polymorphisms were mapped more accurately within the gene compared to previous studies. The genotype distribution was compared in 76 Type 2 diabetic patients and 84 healthy control subjects. No significant differences were found in the distribution of genotypes between diabetic and control subjects at the $p<0.01$ level. In order to study the possible association between quantitative
\end{abstract}

measures of glucose metabolism and these DNA polymorphisms, the fasting glucose and insulin concentrations were compared in the different genotype groups of control subjects and mildly diabetic patients treated with diet. No differences in fasting glucose or insulin concentrations were found at the $p<0.005$ level of significance. In conclusion, no significant associations were found between insulin receptor gene DNA polymorphisms and glucose intolerance.

Key words: Type 2 (non-insulin-dependent) diabetes mellitus, insulin receptors, restriction fragment length polymorphisms, linkage disequilibrium, blood glucose.
Several studies have shown that decreased insulin sensitivity is an important feature in the development of Type 2 (non-insulin-dependent) diabetes mellitus [1,2], and that insulin sensitivity is to a large extent genetically regulated [3-7].

Theoretically, structural or regulatory variants of many genes may determine insulin sensitivity. One obvious candidate is the insulin receptor gene. The importance of this gene for glucose tolerance is illustrated by findings of severe insulin resistance in individuals with mutant insulin receptors [8]. However, none of these mutated insulin receptor genes is known to occur frequently in the population.

Association studies in different racial groups have shown a correlation between Type 2 diabetes and certain DNA polymorphisms of the insulin receptor gene in some populations but not in others [9-13]. We performed a screening study of a genetically homogenous Swedish population with seven restriction fragment length polymorphisms (RFLPs) that span functionally important regions of the insulin receptor gene. The aim was to investigate whether any common genetic variants of the receptor gene - in linkage disequilibrium with these DNA markers - are associated with Type 2 diabetes or variables characterizing glucose intolerance.

\section{Subjects and methods}

\section{Subjects}

The 76 diabetic patients and 84 control subjects in this study were unrelated individuals of Scandinavian origin. All individuals gave informed consent to the study. Characteristics of the two groups are summarized in Table 1 . Since genetic factors are more prominent in lean than in obese diabetic subjects [14], we selected mainly lean diabetic patients. The diagnosis of Type 2 diabetes was performed according to WHO criteria: all subjects with Type 2 diabetes had either a fasting blood glucose exceeding $7.0 \mathrm{mmol} / \mathrm{l}$ at repeated measurements, or a blood glucose of at least $10 \mathrm{mmol} / 12 \mathrm{~h}$ after a $75 \mathrm{~g}$ oral glucose load. None had shown a tendency to ketoacidosis during at least two years of anti-diabetic treatment without insulin. The mean age at the onset of disease was 49.9 years (range $29-$

Table 1. Subjects studied.

\begin{tabular}{lclll}
\hline & No & M/F & Age & BMI $^{\mathrm{a}}$ \\
\hline Diabetic patients & 76 & $57 / 19$ & $56.9(39.0-74.0)$ & $26.1(18.1-39.0)$ \\
Control subjects & 84 & $56 / 28$ & $58.2(45.0-78.0)$ & $24.4(18.1-42.8)$ \\
\hline \multicolumn{7}{l}{ Values are means with ranges within brackets } \\
a Body mass index (BMI) was calculated as weight in kg/(height \\
in $\mathrm{m})^{2}$
\end{tabular}


Table 2. Restriction fragment length polymorphisms (RFLPs) at the insulin receptor locus used in this study

\begin{tabular}{|c|c|c|c|c|c|c|}
\hline \multirow[t]{2}{*}{ RFLP } & \multirow[t]{2}{*}{ Probe } & \multicolumn{2}{|c|}{ Allele } & \multicolumn{2}{|c|}{ Frequency } & \multirow[t]{2}{*}{ Reference } \\
\hline & & No. & Size $^{a}$ & $\begin{array}{l}\overline{\mathrm{Pa}-} \\
\text { tients }\end{array}$ & $\begin{array}{l}\text { Control } \\
\text { subjects }\end{array}$ & \\
\hline PstI & $18-2$ & $\begin{array}{l}1 \\
2\end{array}$ & $\begin{array}{l}1.8 \\
1.5\end{array}$ & $\begin{array}{l}0.15 \\
0.85\end{array}$ & $\begin{array}{l}0.14 \\
0.86\end{array}$ & {$[18]$} \\
\hline XbaI & $13-14$ & $\begin{array}{l}1 \\
2\end{array}$ & $\begin{array}{l}18.0 \\
11.5\end{array}$ & $\begin{array}{l}0.61 \\
0.39\end{array}$ & $\begin{array}{l}0.64 \\
0.36\end{array}$ & {$[13]$} \\
\hline RsaI & $13-14$ & $\begin{array}{l}1 \\
2 \\
3 \\
4 \\
5 \\
6\end{array}$ & $\begin{array}{l}6.7 \\
6.2 \\
6.3 \\
5.8 \\
5.6 \\
3.4\end{array}$ & $\begin{array}{l}0.60 \\
0.39 \\
0.007 \\
0.007 \\
0 \\
0\end{array}$ & $\begin{array}{l}0.55 \\
0.42 \\
0.006 \\
0 \\
0.012 \\
0.012\end{array}$ & [19] \\
\hline SacI-A & $13-16$ & $\begin{array}{l}1 \\
2\end{array}$ & $\begin{array}{l}5.8 \\
5.3\end{array}$ & $\begin{array}{l}0.15 \\
0.85\end{array}$ & $\begin{array}{l}0.15 \\
0.85\end{array}$ & {$[20]$} \\
\hline DraI & $13-16$ & $\begin{array}{l}1 \\
2\end{array}$ & $\begin{array}{l}2.9 \\
1.4\end{array}$ & $\begin{array}{l}0.41 \\
0.59\end{array}$ & $\begin{array}{l}0.36 \\
0.64\end{array}$ & [21] \\
\hline SacI-B & $13-16$ & $\begin{array}{l}1 \\
2\end{array}$ & $\begin{array}{l}9.4 \\
7.0+2.4\end{array}$ & $\begin{array}{l}0.89 \\
0.11\end{array}$ & $\begin{array}{l}0.91 \\
0.09\end{array}$ & {$[20]$} \\
\hline HindIII & $13-16$ & $\begin{array}{l}1 \\
2\end{array}$ & $\begin{array}{l}23 \\
20\end{array}$ & $\begin{array}{l}0.17 \\
0.83\end{array}$ & $\begin{array}{l}0.15 \\
0.85\end{array}$ & {$[21]$} \\
\hline
\end{tabular}

a Size is expressed in kb (kilobase-pairs)

66 years). At the time of the study, 43 of the patients were treated with diet only, 17 also received antidiabetic drugs, and 16 were on insulin treatment. The control subjects were healthy, above 44 years of age with a fasting blood glucose less than $5.2 \mathrm{mmol} / \mathrm{l}$ (mean value $4.3 \mathrm{mmol} / \mathrm{l}$, range $3.0-5.1 \mathrm{mmol} / \mathrm{l}$ ). Venous blood samples were obtained after overnight fasting for determination of glucose and immunoreactive insulin $[15,16]$. The study was approved by the Ethics Committees at Karolinska Hospital and Uppsala University.

\section{RFLP analysis}

DNA was extracted from leucocytes by proteinase $\mathrm{K}$ digestion in SDS followed by ethanol precipitation of DNA [17]. Seven $\mu \mathrm{g}$ of DNA was cleaved with a ten-fold excess of restriction enzyme (New
England Biolabs, Beverly, Mass., USA; or Amersham, Buckinghamshire, UK) for $16-20 \mathrm{~h}$, under conditions specified by the manufacturer. The cleaved DNA was separated on $0.6-1.2 \%$ agarose gels and transferred to GeneScreen Plus membranes (DuPont, Wilmington, Del., USA), using $0.4 \mathrm{~mol} / 1 \mathrm{NaOH}$ and $0.6 \mathrm{~mol} / 1 \mathrm{NaCl}$ as transfer medium.

The insulin receptor cDNA clones pHINSR 18-2 [18] and phINSR 13-1 [19] were kindly provided by Dr. G. I. Bell, University of Chicago. Two subfragments of phINSR 13-1 were used: a 1360 base pair (bp) BgII/BgII fragment, called 13-14, to detect the $\mathrm{XbaI}$ and RsaI polymorphisms; and a 1599 bp PstI/PstI subclone, called phINSR 13-16, to detect the SacI-A and B, DraI, and HindIII polymorphisms (Table 2) [13,18-21]. The probes were labelled with $\left[\alpha^{32} \mathrm{P}\right] \mathrm{dCTP}$ to a specific activity of $10^{8}-10^{9} \mathrm{cpm} / \mu \mathrm{g}$ DNA by random priming [22]. Prehybridization was carried out at $42{ }^{\circ} \mathrm{C}$, for $8-20 \mathrm{~h}$ in $6 \times$ SSC, $10 \times$ Denhardt's Solution, $1 \%$ SDS, and $100 \mu \mathrm{g} / \mathrm{ml}$ denatured salmon sperm DNA. Hybridization was performed at $65^{\circ} \mathrm{C}$ for $20 \mathrm{~h}$ in $6 \times \mathrm{SSC}, 5 \%$ dextran sulphate, $1 \%$ SDS, and $100 \mu \mathrm{g} / \mathrm{ml} \mathrm{de}$ natured salmon sperm DNA. The membranes were washed twice for $15 \mathrm{~min}$ in $0.1 \times \mathrm{SSC}$ and $0.1 \% \mathrm{SDS}$ at $65^{\circ} \mathrm{C}$.

\section{Identification and localization of RFLPs at the insulin receptor locus}

Seven insulin receptor specific RFLP markers were used in this study (Table 2, Fig. 1). The PstI polymorphism has previously been localized to exons 1-3 [18]. The 6.5 kilobase $(\mathrm{kb})$ fragment generated from the 2-allele of the XbaI RFLP $(11.5+6.5 \mathrm{~kb})$ can only be detected with probe phINSR 13-1 covering exons 4-22, but not with probe 13-14 covering exons 7-15. Probe phINSR 13-16, covering exons 14-22, cannot detect this XbaI RFLP at all. Therefore, we localized the XbaI 18/11.5 +6.5 kb RFLP to the region from exon 4 to $5^{\prime}$ of exon 7 (Fig.1). The RsaI polymorphism has earlier been mapped to DNA sequences between exons 9 and 12 of the insulin receptor [20]. We have found that the same polymorphism was also detected with EcoRI (6.0 and $5.5 \mathrm{~kb}$ ), DraI (5.5 and $5.0 \mathrm{~kb}$ ), HindIII (10.7 and $10.2 \mathrm{~kb})$, XbaI ( 9.9 and $9.4 \mathrm{~kb})$, Sacl ( 4.9 and $4.4 \mathrm{~kb})$ and PstI $(9.8$ and $9.3 \mathrm{~kb})$. For these enzymes the analyses were performed on DNA from at least 20 individuals. A few individuals had uncommon RsaI allele-sizes of 6.3,5.8, 5.6 and $3.4 \mathrm{~kb}$ (Table 2). The 6.3 and $5.6 \mathrm{~kb}$ alleles were verified with DraI and HindIII, in contrast to the $5.8 \mathrm{~kb}$ allele that we were not able to verify with these enzymes. No attempt was made to verify the $3.4 \mathrm{~kb}$ allele. The RsaI RFLP can be mapped to the proximity of exons 10 and 11 (Fig. 1), by

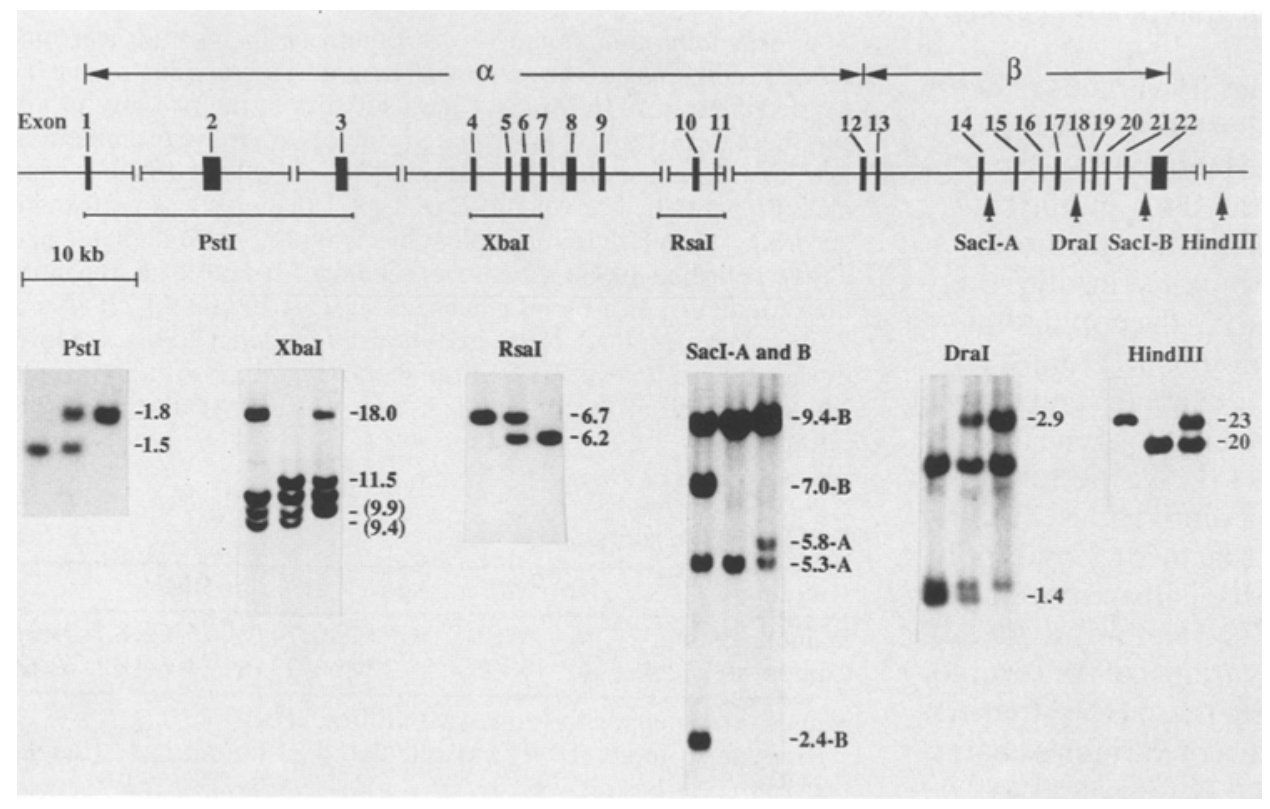

Fig. 1. Map of the human insulin receptor gene and restriction fragment length polymorphisms (RFLPs). The filled boxes denote exons and the thin line denotes introns with interruptions indicating as yet uncharacterized regions of the gene. Below the gene are shown the approximate location of the used RFLP markers. The autoradiograms of Southern blots show the fragment pattern of the different RFLP genotypes. Background information for this figure was taken from references [23-25]. The lanes show, PstI; a, $2 / 2$ homozygote; $b, 1 / 2$ heterozygote; $c$, $1 / 1$ homozygote: XbaI; a, 1/1; b, 2/2;c, $1 / 2$ (the Xbal polymorphic fragments of lengths 9.9 kilobases $(\mathrm{kb})$ and $9.4 \mathrm{~kb}$ correspond to the Rsal RFLP): RsaI; a, $1 / 1 ; b, 1 / 2 ; c, 2 / 2$ : SacI-A and $B$; $a$, $\mathrm{A}-2 / 2$ and $\mathrm{B}-1 / 2 ; \mathrm{b}, \mathrm{A}-2 / 2$ and $\mathrm{B}-1 / 1 ; \mathrm{c}$, A-1/2 and B-1/1: DraI; a, 2/2; b, $1 / 2 ; c$, 1/1: HindIII; a, 1/1; b, 2/2; c, 1/2. Fragments without indicated lengths are non-polymorphic DNA fragments 
comparing with the EcoRI map of the human insulin receptor gene described by Seino et al. [23]. The SacI-A insertion/deletion polymorphism has earlier been characterized in detail [24]. It was also detected with DraI (4.1 and $3.6 \mathrm{~kb})$, HindIII (14.0 and $13.5 \mathrm{~kb}$ ), XbaI $(5.8$ and $5.3 \mathrm{~kb}$ ) and BamHI (7.4 and $6.9 \mathrm{~kb})$. The Rsal and SacI-A RFLPs were the only RFLPs studied that were detected with multiple restriction enzymes.

The DraI 2.9/1.4 kb RFLP was mapped to the intron between exons 17 and 18 (Fig. 1), based on the following results: both the 2.9 and the $1.4 \mathrm{~kb}$ fragments were detected with PCR amplified probes for exons 18 and 19 [25], respectively; an exon 20 specific probe hybridized only to a $4.5 \mathrm{~kb}$ constant band; and the intron between exons 17 and 18 is the only intron in this region long enough [25] to include the difference between the long and the short DraI alleles $(1.5 \mathrm{~kb})$. The SacI-B RFLP with allele sizes 9.4 and $7.0+2.4 \mathrm{~kb}$ could be localized to the intron between exons 21 and 22 by a similar exon specific hybridization analysis (Fig. 1).

The HindIII RFLP with alleles of $23 / 20 \mathrm{~kb}$ was localized approximately $20 \mathrm{~kb} 3^{\prime}$ of exon 17 , as the $20 \mathrm{~kb}$ fragment was the only HindIII fragment detected $3^{\prime}$ of the known HindIII site in intron 17 [24].

\section{Statistical analysis}

Averages are presented as arithmetic means for normally distributed continuous variables, and when indicated, as medians for variables deviating from the normal distribution. Genotype frequencies of the diabetic and control subjects were compared using $2 \times 3$ or $2 \times 2$ contingency tables and chi-square analysis of independence. The fasting concentrations of blood glucose and insulin in the different genotype groups were compared using the non-parametric Kruskal-Wallis one-way analysis of variance.

\section{Results}

RFLPs at the insulin receptor locus

The approximate localizations of the seven RFLP markers at the insulin receptor locus used in this study are shown in Figure 1. Four of these RFLPs (XbaI, DraI, SacI-B, HindIII) were mapped more accurately compared to previous studies as described in Subjects and methods. The SacI-A polymorphism has previously been shown to be an insertion/deletion polymorphism [24]. During the course of these studies we found that at least the $1,2,3$ and 5 alleles of the RsaI polymorphism behave as an insertion/deletion polymorphism also detectable with a number of other restriction enzymes. For further details on the RFLPs, see Subjects and methods.

\section{Distribution of RFLP-genotypes in Type 2 diabetic patients and control subjects}

The study comprised 76 patients with Type 2 diabetes and 84 control subjects. The control subjects were selected for fasting blood glucose levels below $5.2 \mathrm{mmol} / \mathrm{l}$ and age above 44 years. Characteristics of the study groups are presented in Table 1. For the seven RFLP markers used, no significant differences were found in the allele frequencies between the diabetic and control subjects (Table 2). Since we consider it more informative to compare genotype distributions rather than allele frequencies when the mode of transmission is unknown, we also compared the
Table 3. Distribution of genotypes in patients with Type 2 (non-insulin-dependent) diabetes and healthy control subjects

\begin{tabular}{|c|c|c|c|c|c|c|}
\hline \multicolumn{2}{|c|}{ Genotypes } & \multicolumn{2}{|c|}{ Patients } & \multicolumn{2}{|c|}{ Control subjects } & \\
\hline & & $n$ & $\begin{array}{l}\text { (fre- } \\
\text { quency) }\end{array}$ & $n$ & $\begin{array}{l}\text { (fre- } \\
\text { quency) }\end{array}$ & \\
\hline PstI: & $\begin{array}{l}1 / 1 \\
1 / 2 \\
2 / 2\end{array}$ & $\begin{array}{r}0 \\
23 \\
53\end{array}$ & $\begin{array}{l}(0.00) \\
(0.30) \\
(0.70)\end{array}$ & $\begin{array}{r}3 \\
18 \\
63\end{array}$ & $\begin{array}{l}(0.04) \\
(0.21) \\
(0.75)\end{array}$ & $\begin{array}{l}\chi^{2}=0.32 \\
p=0.57\end{array}$ \\
\hline XbaI: & $\begin{array}{l}1 / 1 \\
1 / 2 \\
2 / 2\end{array}$ & $\begin{array}{l}28 \\
37 \\
11\end{array}$ & $\begin{array}{l}(0.37) \\
(0.49) \\
(0.14)\end{array}$ & $\begin{array}{l}34 \\
39 \\
11\end{array}$ & $\begin{array}{l}(0.40) \\
(0.46) \\
(0.13)\end{array}$ & $\begin{array}{l}\chi^{2}=0.19 \\
p=0.91\end{array}$ \\
\hline RsaI: & $\begin{array}{l}1 / 1 \\
1 / 2 \\
2 / 2 \\
1 / 3 \\
1 / 4 \\
2 / 5 \\
6 / 6\end{array}$ & $\begin{array}{r}25 \\
39 \\
10 \\
1 \\
1 \\
0 \\
0\end{array}$ & $\begin{array}{l}(0.33) \\
(0.51) \\
(0.13) \\
(0.01) \\
(0.01) \\
(0.00) \\
(0.00)\end{array}$ & $\begin{array}{r}31 \\
29 \\
20 \\
1 \\
0 \\
2 \\
1\end{array}$ & $\begin{array}{l}(0.37) \\
(0.35) \\
(0.24) \\
(0.01) \\
(0.00) \\
(0.02) \\
(0.01)\end{array}$ & $\begin{array}{l}\chi^{2}=5.22 \\
p=0.07\end{array}$ \\
\hline SacI-A: & $\begin{array}{l}1 / 1 \\
1 / 2 \\
2 / 2\end{array}$ & $\begin{array}{r}2 \\
19 \\
55\end{array}$ & $\begin{array}{l}(0.03) \\
(0.25) \\
(0.72)\end{array}$ & $\begin{array}{r}1 \\
23 \\
60\end{array}$ & $\begin{array}{l}(0.01) \\
(0.27) \\
(0.71)\end{array}$ & $\begin{array}{l}\chi^{2}=0.002 \\
p=0.96\end{array}$ \\
\hline DraI: & $\begin{array}{l}1 / 1 \\
1 / 2 \\
2 / 2\end{array}$ & $\begin{array}{l}15 \\
33 \\
28\end{array}$ & $\begin{array}{l}(0.20) \\
(0.43) \\
(0.37)\end{array}$ & $\begin{array}{l}12 \\
37 \\
35\end{array}$ & $\begin{array}{l}(0.14) \\
(0.44) \\
(0.42)\end{array}$ & $\begin{array}{l}\chi^{2}=0.94 \\
p=0.62\end{array}$ \\
\hline Sacl-B: & $\begin{array}{l}1 / 1 \\
1 / 2 \\
2 / 2\end{array}$ & $\begin{array}{r}60 \\
15 \\
1\end{array}$ & $\begin{array}{l}(0.79) \\
(0.20) \\
(0.01)\end{array}$ & $\begin{array}{r}72 \\
9 \\
3\end{array}$ & $\begin{array}{l}(0.86) \\
(0.11) \\
(0.04)\end{array}$ & $\begin{array}{l}\chi^{2}=0.84 \\
p=0.36\end{array}$ \\
\hline HindIII: & $\begin{array}{l}1 / 1 \\
1 / 2 \\
2 / 2\end{array}$ & $\begin{array}{r}2 \\
22 \\
52\end{array}$ & $\begin{array}{l}(0.03) \\
(0.29) \\
(0.68)\end{array}$ & $\begin{array}{r}2 \\
21 \\
61\end{array}$ & $\begin{array}{l}(0.03) \\
(0.25) \\
(0.73)\end{array}$ & $\begin{array}{l}\chi^{2}=0.17 \\
p=0.68\end{array}$ \\
\hline
\end{tabular}

When the number in one homozygote group was less than 5 , this group was added to the heterozygote group before performing the $\chi^{2}$ analysis. For the RsaI genotypes, the analysis was carried out on the three most common genotype groups

distribution of the RFLP genotypes between the diabetic and control subjects (Table 3 ). Four of the RFLPs showed very rare homozygotes that were pooled with the heterozygotes before the chi-square analysis. The level of significance was chosen as $p<0.01$ in order to correct for the number of comparisons made. None of the RFLPs showed any significant difference in the genotype distribution between patients and control subjects. The RsaI polymorphism was closest to the significance level, with $p=0.07$. In the control subjects, a certain deviation from Hardy-Weinberg equilibrium in the distribution of RsaI genotypes, $\left(\chi^{2}=5.45,1 \mathrm{df}, p<0.025\right)$, parallelled the difference in genotype distribution between diabetic and control subjects. However, neither the distribution of RsaI genotypes or any other RFLP genotypes differed significantly from the expected Hardy-Weinberg distribution at the $p<0.01$ level.

\section{Phenotypic characteristics of the different genotypes}

Considering the heterogeneity and complex aetiology of Type 2 diabetes, an attempt was made to associate insulin receptor genotypes not only with Type 2 diabetes but also with some phenotypic characteristics of this disease. We compared the fasting glucose levels and insulin concentra- 
Table 4. Phenotypic characteristics of patients with Type 2 (non-insulin-dependent) diabetes treated with diet and control subjects divided into different genotype groups

\begin{tabular}{lllll}
\hline Genotype $n$ & $\begin{array}{l}\text { Fasting glucose } \\
(\mathrm{mmol} / \mathrm{l})\end{array}$ & $\begin{array}{l}\text { Kruskal- } \\
\text { Wallis test }\end{array}$ & $\begin{array}{l}\text { Fasting IRI } \\
\left(\mathrm{pmol} / 1 \times 10^{2}\right)\end{array}$ & $\begin{array}{l}\text { Kruskal- } \\
\text { Wallis test }\end{array}$ \\
\hline Diabetic patients & & &
\end{tabular}

PstI

$1 / 1 \quad 0$

$1 / 2 \quad 14$

$2 / 2 \quad 29$

$6.7(6.0-8.3)$

$7.7(5.9-8.6)$

$p=0.63^{b}$

$1.3(1.2-1.8)$

$p=0.18^{\mathrm{b}}$

$\mathrm{XbaI}$

$1 / 1 \quad 21$

$1 / 2$

$2 / 2$

$7.0(5.9-8.5)$

$7.0(6.1-9.6)$

$6.0(5.4-6.3)$

$p=0.27$

$0.9(0.7-1.3)$

$1.3(1.1-2.0)$

$1.2(0.7-1.5)$

$p=0.10$

Rsal

$1 / 1 \quad 14$

$1 / 2$

$2 / 2$

$7.9(6.6-9.1)$

$6.9(6.0-8.7)$

$5.7(4.6-6.5)$

$1.3(0.9-2.2)$

$p=0.02 \quad 1.2(0.9-1.6)$

$1.0(0.7-1.3)$

$p=0.18$

SacI-A

$1 / 1$

$1 / 2$

$2 / 2$

18.6

$14 \quad 7.3(5.6-9.1)$

$6.7(6.0-8.4)$

$p=0.68$

0.6

$1.3(0.6-2.0) \quad p=0.40$

$1.2(0.8-1.4)$

$7.3(5.8-8.6)$

$6.8(5.3-9.1)$

$7.0(6.2-8.3)$

$p=0.92$

$1.2(0.8-2.1)$

$1 / 1$
$1 / 2$

$2 / 2$

21
14

$p=0.92$

$1.3(0.7-1.5)$

$1.2(0.8-1.4)$

$p=0.95$

SacI-B

$1 / 1$
$1 / 2$

$1 / 2$

34

$7.0(5.9-8.6)$

$6.4(5.9-9.7)$

$p=0.43$

$1.2(0.8-1.8)$

9.7

$1.2(0.8-1.4)$

1.1

HindIII

$1 / 1$

$1 / 2$

$2 / 2$

5.9

$9.0(6.4-10.8)$

1.1

$6.9(5.9-8.3)$

$p=0.21$

$1.3(0.9-1.6)$

$1.2(0.8-1.5)$

$p=0.81$

Control subjects

PstI

$1 / 1 \quad 3 \quad 4.0(3.5-4.2)$

$1 / 2 \quad 18 \quad 4.4(4.2-4.6)$

$2 / 2 \quad 63 \quad 4.3(3.9-4.7)$

$p=0.35$

$1.3(1.0-1.4)$

$1.0(0.7-1.4) \quad p=0.56$

$\mathrm{Xbal}$

$1 / 1$

$1 / 2$

34

$4.3(3.9-4.7)$

$0.9(0.6-1.3)$

$0.9(0.4-1.4)$

$0.9(0.4-1.4)$
$1.0(0.6-1.3)$

$0.9(0.7-1.2)$

$p=0.99$

$4.1(3.9-4.5)$

$p=0.40$

$4.5(4.0-4.8)$

$4.4(4.1-4.5)$

$4.2(3.8-4.6)$

$p=0.32$

$0.9(0.6-1.4)$

$0.9(0.6-1.4)$
$0.9(0.7-1.3)$

$1.1(0.8-1.3)$

$p=0.69$

$2 / 2$

20

3.0

$\begin{array}{lr}1 / 1 & 1 \\ 1 / 2 & 23\end{array}$

1
23

$4.3(4.2-4.5)$

$4.4(3.9-4.6)$

$p=0.23$

0.7

0.7
1.0

$(0.7-1.4)$

$p=0.51$

DraI

$1 / 1$

$1 / 2$

$2 / 2$

$4.4(4.0-4.7)$

$4.3(4.1-4.5)$

$4.4(3.9-4.6)$

$p=0.90$

$1.1(0.8-1.4)$

$0.9(0.7-1.3)$

$0.9(0.6-1.4)$

$p=0.55$

$4.3(4.0-4.6)$

$4.5(4.2-4.6)$

$4.1(4.0-4.4)$

$p=0.90$

$1.0(0.6-1.3)$

$0.8(0.5-1.2)$

$1.1(1.1-1.6)$

$p=0.27$

$1.0(0.9-1.1)$

$0.8(0.6-1.2)$

$1.0(0.7-1.4)$

Values are medians with lower and upper quartiles within brackets.

${ }^{2}$ IRI = immunoreactive insulin;

b a Mann-Whitney U-test was performed instead of a Kruskal-Wallis test in this case, since there were no observations in the $1 / 1$ homozygote group 
tions between the different genotype groups. In order to avoid effects of the treatment on the fasting blood glucose and insulin concentrations, diabetic patients treated with insulin or oral antidiabetic agents were excluded from these analyses.

None of the genotype groups defined by the seven RFLP markers demonstrated any significant differences in the concentration of fasting glucose or immunoreactive insulin (Table 4). Since age and BMI are variables known to influence the blood glucose and insulin levels, we also compared age and BMI between the different genotypes. No significant differences were found for age and BMI between the genotype groups (data not shown). The nonparametric Kruskal-Wallis one-way variance test was used, since the values in some of the groups were not normally distributed. In order to compensate for multiple comparisons, $p<0.005$ was chosen as the minimum requirement for significance. Therefore the difference in the fasting glucose levels observed in patients with different RsaI genotypes was not significant $(p=0.02)$.

\section{Discussion}

The objective of the present study was to examine whether any common genetic variants of the insulin receptor gene - in linkage disequilibrium with RFLP markers - are associated with Type 2 diabetes or phenotypic variables characterizing glucose intolerance. No significant associations between insulin receptor RFLPs and Type 2 diabetes, or fasting glucose and insulin concentrations, were found after screening 160 individuals. The slight over-representation of homozygotes for the RsaI $6.2 \mathrm{~kb}$ 2-allele among control subjects $(p=0.07)$ is probably explained by the deviation from Hardy-Weinberg equilibrium seen in this group, since the allele frequencies are similar in the diabetic and control groups. The genotypes defined by the RsaI marker showed a difference in fasting glucose concentrations in patients treated with diet only, in that the 2-allele was associated with lower blood glucose $(p=0.02)$. However, this difference was non-significant at a level adjusted for multiple comparisons. The same tendency, to a lesser extent, was also seen in the control subjects (Table 4). In the statistical analyses, the levels of significance were lowered in order to compensate for the multiple comparisons made (several RFLPs and parameters). Even if no significant association was found between RFLP markers and the disease at the level of significance chosen, it is difficult to exclude contributions of insulin receptor polymorphisms to Type 2 diabetes based on a subject material of our size. Several factors influence the possibility of detecting a linkage disequilibrium between a dysfunctional insulin receptor gene, involved as a susceptibility factor for Type 2 diabetes, and an RFLP marker. As discussed in detail by Cox and Bell [26], the number of individuals required to detect a statistically significant association depends on the frequency of the RFLP allele, the degree of linkage disequilibrium, the quantitative contribution of the locus to disease susceptibility, as well as the mode of transmission of the susceptibility.
It is likely that Type 2 diabetes, due to differences in aetiology and linkage disequilibrium, is associated with different genes, or different markers of the same gene in different populations. An association between Type 2 diabetes and the $5.8 \mathrm{~kb}$ allele of the SacI-A RFLP of the insulin receptor gene was observed in a study of White and Hispanic subjects [11], while no such genotype differences were observed in Japanese subjects [10], or in the present study of Scandinavian subjects. A study including 394 Mexican-Americans indicated an increased risk for homozygotes for the rare RsaI $3.4 \mathrm{~kb}$ 6-allele to be affected with Type 2 diabetes [12]. The only subject in our study of Scandinavians with this allele was a homozygote with normal glucose tolerance. A recent study of ChineseAmericans, where haplotypes at the insulin receptor locus were constructed using a statistical method, showed an overrepresentation of two haplotypes defined with the three RFLP markers XbaI, RsaI and KpnI among control subjects as compared to patients with Type 2 diabetes [13]. No differences in allele frequencies for these RFLPs were detected between patients and control subjects in that study.

In conclusion, no significant associations could be identified between RFLPs at the insulin receptor locus and Type 2 diabetes or phenotypic variables characterizing glucose intolerance.

Acknowledgements. We are grateful to Ms. M. Olsson for excellent technical assistance, and to Dr. G.I.Bell for providing clones phINSR $18-2$ and phINSR 13-1. This study was supported by the Swedish Medical Research Council, the Knut and Alice Wallenberg Foundation, the Bank of Sweden Tercentenary Foundation, the Royal Swedish Academy of Sciences, and the Magnus Bergvall's Stiftelse.

\section{References}

1. Olefsky JM, Ciaraldi TP, Kolterman OG (1985) Mechanisms of insulin resistance in non-insulin-dependent (Type II) diabetes. Am J Med 79 [Suppl 3B]: 12-22

2. Lillioja S, Mott DM, Howard BV et al. (1988) Impaired glucose tolerance as a disorder of insulin action. Longitudinal and crosssectional studies in Pima Indians. N Engl J Med 318: 1217-1225

3. Iselius L, Lindsten J, Morton NE, Efendić S, Cerasi E, Haegermark A, Luft R (1985) Genetic regulation of the kinetics of glucose-induced insulin release in man. Clin Genet 28: 8-15

4. Haffner SM, Stern MP, Hazuda HP, Pugh JA, Patterson JK (1986) Hyperinsulinemia in a population at high risk for non-insulin-dependent diabetes mellitus. N Engl J Med 315: 220-224

5. Lillioja S, Mott DM, Zawadzki JK et al. (1987) In vivo insulin action is familial characteristic in non-diabetic Pima Indians. Diabetes 36: 1329-1335

6. Haffner SM, Stern MP, Hazuda HP, Mitchell BD, Patterson JK (1988) Increased insulin concentrations in non-diabetic offspring of diabetic parents. N Engl J Med 319: 1297-1301

7. Bogardus C, Lillioja S, Nyomba BL et al. (1989) Distribution of in vivo insulin action in Pima Indians as mixture of three normal distributions. Diabetes 38: 1423-1.432

8. Taylor SI, Kadowaki T, Kadowaki H, Accili D, Cama A, McKeon C (1990) Mutations in insulin-receptor gene in insulinresistant patients. Diabetes Care 13: 257-279

9. Takeda J, Seino Y, Yoshimasa Y et al. (1986) Restriction fragment length polymorphism (RFLP) of the human insulin receptor gene in Japanese: its possible usefulness as a genetic marker. Diabetologia 29: 667-669 
10. Li SR, Oelbaum RS, Stocks J, Galton DJ (1988) DNA polymorphisms of the insulin receptor gene in Japanese subjects with non-insulin-dependent diabetes mellitus. Hum Hered 38: 273276

11. McClain DA, Henry RR, Ullrich A, Olefsky JM (1988) Restriction-fragment-length polymorphism in insulin-receptor gene and insulin resistance in NIDDM. Diabetes 37: 1071-1075

12. Raboudi SH, Mitchell BD, Stern MP, Eifler CW, Haffner SM, Hazuda HP, Frazier ML (1989) Type II diabetes mellitus and polymorphism of insulin-receptor gene in Mexican Americans. Diabetes 38: 975-980

13. Xiang K-S, Cox NJ, Sanz N, Huang P, Karam JH, Bell GI (1989) Insulin-receptor and apolipoprotein genes contribute to development of NIDDM in Chinese Americans. Diabetes 38: 17-23

14. Köbberling J, Tillil H (1982) Empirical risk figures for first degree relatives of non-insulin dependent diabetics. In: Köbberling J, Tattersall R (eds) The genetics of diabetes mellitus. Sereno Symposia No 47. Academic Press, London New York, pp 201-209

15. Wajngot A, Luft R, Efendić S (1983) Oral glucose tolerance test and insulin sensitivity in low insulin responders. Acta Endocrinol 104: $77-84$

16. Pollare T, Lithell H, Selinus I, Berne C (1988) Application of prazosin is associated with an increase of insulin sensitivity in obese patients with hypertension. Diabetologia $31: 415-420$

17. Bell GI, Karam JH, Rutter WJ (1981) Polymorphic DNA region adjacent to the 5'end of the human insulin gene. Proc Natl Acad Sci USA 78: 5759-5763

18. Sanna MA, Bell GI, Cao A, Pirastu M (1986) Three RFLPs for the insulin receptor gene INSR: EcoRI, PstI, HindIII. Nucleic Acids Res 14:6776

19. Shaw DJ, Bell GI (1985) RsaI polymorphism at the insulin receptor locus (INSR) on chromosome 19. Nucleic Acids Res 13: 8661
20. Elbein SC, Corsetti L, Ullrich A, Permutt MA (1986) Multiple restriction fragment length polymorphisms at the insulin receptor locus: a highly informative marker for linkage analysis. Proc Natl Acad Sci USA 83: 5223-5227

21. Sten-Linder M, Stern I, Bell GI, Luthman H (1989) Human insulin receptor RFLPs detected by HindIII and Dral. Nucleic Acids Res 17: 1277

22. Feinberg AP, Vogelstein B (1984) A technique for radiolabeling DNA restriction endonuclease fragments to high specific activity. Analyt Biochem 137: 266-267

23. Seino S, Seino M, Nishi S, Bell GI(1989) Structure of the human insulin receptor gene and characterization of its promoter. Proc Natl Acad Sci USA 86: 114-118

24. Elbein SC (1989) Molecular and clinical characterization of an insertional polymorphism of the insulin-receptor gene. Diabetes 38: $737-743$

25. Seino S, Seino M, Bell GI (1990) Human insulin-receptor gene. Partial sequence and amplification of exons by polymerase chain reaction. Diabetes 39: 123-128

26. Cox NJ, Bell GI (1989) Perspectives in diabetes. Disease associations. Chance, artifact, or susceptibility genes? Diabetes 38 : 947-950

Received: 25 September 1990

and in revised form: 29 November 1990

Dr. H. Luthman

Department of Clinical Genetics

Karolinska Institute

Karolinska Hospital

S-10401 Stockholm

Sweden 